Fulong Wu, Roger Keil (2020) "Changing the geographies of sub/urban theory: Asian perspectives," Urban Geography (forthcoming)

\title{
Changing the geographies of sub/urban theory: Asian perspectives
}

\author{
Fulong $\mathrm{Wu}^{1}$ and Roger Keil ${ }^{2}$
}

1 Bartlett School of Planning, University College London, London, UK email: fulong.wu@ucl.ac.uk

2 Faculty of Environmental Studies, York University, Toronto, Canada email: rkeil@yorku.ca

\section{Abstract:}

This special issue examines the intersection of global suburbanisation and Asian urbanism. The papers provide a perspective from the examination of peripheral areas in fast growing Asian metropolitan regions. From the standpoint of the peripheral space of Jakarta, Kusno challenges the prediction that globalisation and the logic of capital accumulation would eventually lead to a complete urban area, leaving behind the rural. Irregular settlements (kampung) remain as 'middling urbanism'. From the vantage point of Gurgaon at the edge of New Delhi, Gururani argues that many villages straddle the ruralurban divide and are embedded in property development, which reveals an essentially rural question. Describing urban villages, new towns and gated estates in peri-urban Guangzhou, Li et al. portray an assemblage of the local state, villagers, real estate developers and middle-class consumers. Investigating the operation of transit-oriented development in Shanghai, Shen and Wu reveal how the concept is borrowed by key state-owned developers to finance infrastructure development, thus serving a new purpose other than that imposed by the financial logic of global investors. Without proposing a concept of Asian suburbanism, the papers depict a complex urban world in Asia.

Keywords: suburbia, Asian urban geography, peri-urbanisation, suburbanisation 
Funded by the major research initiative Global Suburbanisms (www.yorku.ca/suburbs), this special issue examines the intersection of global suburbanisation and Asian urbanism. Framed by Ananya Roy's notion of changing 'geographies of theory' (Roy, 2009) and consciously pursuing comparative urban studies through 'theorising from elsewhere' (Robinson, 2016), this collection of papers provides a perspective from the examination of peripheral areas in fast growing Asian metropolitan regions. From the developments on the ground, we speculate on theoretical and methodological propositions.

This major research initiative aims for a global perspective in approaching the phenomenon of worldwide suburbanisation, by which we mean 'the combination of noncentral population and economic growth with urban spatial expansion' (Ekers, Hamel, \& Keil, 2015, p. 22). As demonstrated by recent publications by this initiative (Hamel \& Keil, 2015; Keil, 2018b; Keil \& Wu forthcoming), the team approaches peripheral development from many vantage points beyond the restricted view of 'suburbanisation'. We view peripheral developments as part of the contemporary urban world. This collection, as a part of this major research initiative, focuses on Asian (sub)urbanism. From a particular partial 'geography' of the urban world, we discuss peripheral informal settlements (Kusno), coexisting agrarian and urban dynamics (Gururani), multiple assemblage-like development forms such as gated communities, economic development zones and new towns, and rural villages (Li et al.) and the financing of infrastructure in peri-urban areas (Shen and $\mathrm{Wu}$ ), in addition to the classical topics of urban expansion, sprawl, density and compactness in suburbanisation research. From these particular peripheral development forms, this collection interrogates how the history (colonial / semi-colonial / socialist) and its past social and spatial configuration (e.g. previous rural settlements) interface with modern and global political economic changes.

In urban theory, what defines global, planetary or worldly has been the subject of much debate and criticism (Sheppard, Leitner, \& Maringanti, 2013; Keil, 2018a. See in this journal Wilson \& Jonas, 2018; Jefferson, 2018; Merrifield, 2018; Keil, 2018c. For an interesting application to debates and developments in Asia, see Khan \& Karak 2018). Related concepts like "extensive" urbanisation have received particular treatment when refracted in the context of Asian urbanism, both real and theorised (Simone, 2019). Asian 
urbanisation has also been the subject of recent speculation on the proliferation of particular forms of unbound mega-urbanisation (Friedmann \& Sorensen, 2019).

Urbanism, in one representation, 'has come to refer to a distinct kind of site (the city), separable from other rural places, and taken to be a hallmark of modernism, progress, development, and the metropole - the opposite of provincialism. At the same time, urbanism is associated with a set of social ills, the dark side of development contrasted with an idyllic rural past' (Sheppard, Leitner, Maringanti, 2013, p. 894). From the standpoint of the cases under scrutiny here, the collection continues these conversations. For example, as Chinese cities have been transformed by the endeavour of building the 'world factory' (Wu, 2016), suburban new towns have been actively promoted as a strategy of capital accumulation (Shen \& Wu 2017). But the building of the peri-urban area involves multiple actors including real estate developers and rural villagers $(\mathrm{Li}$, Chen, $\& \mathrm{Wu}$, in this collection), producing their distinct spatial forms (gated estates and upgraded villages). In a new town near the Indian capital, hundreds of developers of different scales became involved in frenetic land development, negotiating and contesting with landowners (Gururani in this collection; Gururani \& Dasgupta, 2018). Land development in peripheral urban areas necessarily has to negotiate with the colonial and pre-reform structure of land tenure. Similarly, in Indonesian and Chinese cities, these previous villages have not been wiped out but rather are being transformed and upgraded through the 'entrepreneurial spirit' of villagers ( $\mathrm{Li}$, Chen, \& Wu in this collection) and kampung developers (Kusno). On the other hand, large infrastructure projects such as suburban metro lines in Shanghai and elsewhere in China resorted to some new development concepts such as transit-oriented development (TOD) and land value capture through 'rail + property' (Shen \& Wu in this collection). But their exact applications depend upon very local Chinese practices - they may not follow the original intention when these concepts were invented elsewhere.

In the process of these studies, researchers critique the concept of 'Asian' sub/urbanism itself. While the idea of a specifically 'Asian' urbanism has been put forward as a particularly powerful intervention in post-colonial debates, closer scrutiny of Asia's sub/urban and peripheral variety may cast new light on the concept itself. The term 'Asian' urbanism must necessarily be a chaotic concept if we look at the entire Asian continent. To be sure, there are some similarities across this vast continental territory. 
Among them are, for example, the "massive" state-led, high density, predominantly high rise forms of peripheral urbanisation that we see from Istanbul's Anatolian suburbs to the peripheries of Seoul or Hanoi (Güney, Keil \& Üçoğlu, 2019). There is plenty of mid-density suburbanisation - think of the New Town of Anting in the Shanghai region - which we also find in Europe and Latin America as well as (often gated) low rise, low density suburbs that look (and are often appropriately named) "American". At the same time, the entire continent continues to show tendencies of informal peripheral urbanisation, from the fast changing Turkish gecekondu to the Indonesian kampung. And - much in contrast to, for instance, the European or North American cases of suburban land development and more in line with African patterns of urbanisation - rural land economies and agricultural socio-spatial relations persist in peri-urban Asia from the Bosporus to the East China Sea (Harris \& Lehrer, 2018). If we include only China (East Asia), India (South Asia), and Indonesia (Southeast Asia), as we do in this special issue, the picture is more incoherent in some ways that are more than just geographical - their different development histories, for example. However, the intention in this collection is not to propose such an idea of 'Asian' sub/urbanism as a concept. Rather, the papers in this collection, although they do not speak to each other directly, launch observations very locally at the particular peripheral sites in these metropolises. Here, 'the inclusion of the Global South in the debate on global suburbanism(s) is not a mere addition of more empirical cases to an existing script of peripheral expansion. It is the acknowledgement that the script of urban theorising has to be rewritten from scratch' (Keil, 2013, p. 14).

The papers in this collection do not start from a vantage point in the central area from which to see the suburban as a relocation of population, or inside-out residential spatial processes. They essentially take a post-suburbia view (post-, in the sense of plural dynamics, residential, industrial, infrastructural, financial, as well as broadly urban and rural dynamics). In fact, their theoretical proposition is 'after suburbia' (after, in the sense that they do not apply a predefined approach to assume that it must be an 'urban' phenomenon (Gururani), disappearing rurality and its associated tradition (Kusno), unified spatial expansion ( $\mathrm{Li}$, Chen, \& Wu), a borrowed global urban concept or financial tool (Shen \& Wu). Instead, they are sensitive to the history and local contexts: a region's colonial past and landowning castes (Gururani), emerging functionality and governance: the necessary absence of public housing and accommodation of semi-proletarian migrants (Kusno), multiple actors and agencies: the state, real estate developers, large 
enterprises, and local village entrepreneurs ( $\mathrm{Li}$, Chen, \& Wu), and specific political economic conditions and funding regimes: infrastructure as physical and financial tools (Shen \& Wu). Together they provide empirically supported decentralised conversations with theory (Peck, 2015) and continue to enrich a post-suburban comparative research field (Phelps \& Wu, 2011; Charmes \& Keil, 2015).

Before we offer concluding remarks on the theoretical implications of these papers, we provide a reading of their individual context-sensitive observations and arguments.

The peripheral area of Southeast Asian cities is characterised by a mixture of villages and towns, known as desakota. The development of these messy spaces goes beyond insideout suburbanisation. It is a process of urbanisation of traditional rural areas. Kusno (2020) examines the informal or irregular settlements, known as kampung in Indonesian, in this zone of transition. The kampung, strictly speaking, is not entirely the new built. It may originate from former rural settlements; its development does not necessarily extend from the city centre. The kampung provides important social and economic functions and as an informal settlement it is not an isolated enclave but rather maintains extensive links with the formal economy. Because the informal space is imperative for the running of the economy and society, it is not in danger of being eliminated. Kusno argues that it will persist, occupying the middle position, connecting the traditional and modern components of Southeast Asian cities. From this middle position, the kampung develops its own power in the politics of development, as the state wants to sustain it as part of the statecraft of indirect rule. It maintains a complex land tenure, and newer kampung constantly evolve along with self-propelled upgrading into 'middle class' rental spaces. From the standpoint of the peripheral space of Jakarta, Kusno challenges the assumption that the logic of capital accumulation will eventually lead to a completely urban area, leaving behind the rural, through proletarianisation and the absorption of labour power; instead, he argues that peri-urban areas may be the sites of semi-proletarianisation and sustained urban and rural duality. He thus conceives a scenario of 'middling urbanism'.

From the vantage point of Gurgaon, an agro-pastoral edge of New Delhi, Gururani (2020) similarly argues that at this frontier of India's urbanisation we see 'an urbanism that does not erase or assimilate the rural but an urbanism in which agrarian and urban dynamics sustain and produce each other.' This peripheral area of India's national capital is in fact 
'a world of villages'. She argues that it is more appropriate to characterise the peri-urban area as 'cities in a world of villages' rather than a relocation from the central to suburban areas, because not only do many villages straddle the rural-urban divide but also they are not part of a completely urbanised fabric. Private rental housing rather than public housing provides accommodation for thousands of migrant workers. The villages also provide infrastructural services to make urban life possible. Moreover, to understand the landscape of development, it is imperative to examine big landowning castes. The social structure of larger landholdings continues to influence the process of land development. The villages persist in the midst of property development for the city of Gurgaon. The division between the planned residential area and the boundary of villages remains, intensifying the core of villages because of space constraints. Thus, while the villages are embedded in a new property regime, the politics of caste and class continue to be salient. Hence, this is the agrarian question meeting the urban question.

Both Southeast Asian informal settlements and Indian persistent villages in peri-urban areas resonate in China. Chinese villages are encircled by the expansion of cities and become 'urban villages' (chengzhongcun). But China also sees the development of largescale formal residential estates in addition to rural villages. Li, Chen, and Wu (2020) prefer to describe this heterogeneous peripheral area as an assemblage, here mainly consisting of three types: new gated enclaves, new towns, and remaining villages that are becoming urban. After a quick scrutiny of the notion of 'post-suburbia', Li, Chen, and Wu unpack the meaning of 'post' in terms of various actors and their agencies. They look at the peripheral area of Guangzhou in China, and identify the components of 'super large estates' that are built into a private city, new towns evolved out of former development zones, and suburban villages near wholesale markets. The key drivers for these developments are different. New towns are more or less state projects intended to become new economic hubs, while urban villages represent more the 'entrepreneurial spirit' of famers and their collectives. In super large private housing estates, property developers and middle-class consumers play a significant role. Li, Chen, and Wu argue that the development of these super large estates has led to a more fragmented peripheral space. They concur that the Chinese peri-urban area is a mixture of suburban bourgeois utopia from the Global North and informality from the Global South (Wu \& Shen 2015). 
While the previous three papers emphasise the rural and agrarian nature of the periphery of Asian cities, Shen and Wu (2020) examine how the circulation and deployment of such development concepts as transit-oriented development (TOD) in the periphery of Shanghai have served a different purpose from the original intention. The development, through linking land and property development, facilitates infrastructure funding in the peri-urban area and promotes its growth. Such key infrastructure as the No. 9 metro line in Shanghai opened up space for development in a place far from the central area. Shen and Wu pay more attention to the formal component of development, especially the railproperty link, but also note a heterogeneous residential space encompassing the wealthy, the middle classes and migrants (Shen \& Xiao, 2019). The new metro line opened up the possibility for residential relocation, seemingly resembling the classic notion of suburbanisation. But at the same time, they note a series of consequential changes brought about by key infrastructure development. When looking at the new town of Songjiang, for example, they argue that it is a process of 'urbanisation of the suburbs', as new manufacturing developments in the periphery attracted an influx of migrant workers. To understand this infrastructure development, Shen and Wu examine the role of key state-owned developers known as urban development corporations (chengtou) and complex negotiations between developers, district and municipal governments, and their agents. They reveal that the so-called TOD here actually serves as a financing instrument, reflecting a state-supported, transit-led suburbanisation, in a context where the state strategically deploys market instruments (Wu, 2018).

A final remark about this special issue, as an introduction to its rich empirical materials, is that each paper does not compare multiple cities, yet they are comparative in spirit. They do not even intend to propose a coherent and unified concept such as 'Asian suburbanism'. Rather, they depict a picture of dynamic peripheral areas of Asian metropolitan areas which are becoming a complex urban world that is not understood as an outcome of transition from the countryside to cities. Informal, irregular settlements persist; they are upgraded and serve new functionalities. They connect the new world to the rurality of the past, while new infrastructure is built with 'modern' and financialised development approaches. As research sites, these peripheral locations in known or unknown small places open up our minds for more locally sensitive studies which have implications beyond their particular localities. 


\section{Reference}

Charmes, Eric, \& Keil, Roger (2015). The politics of post-suburban densification in Canada and France. International Journal of Urban and Regional Research, 39(3), 581-602.

Ekers, Michael, Hamel, Pierre, \& Keil, Roger (2015). Governing suburbia: modalities and mechanisms of suburban governance. In Pierre Hamel \& Roger Keil (Eds.), Suburban governance: A global view (pp. 19-48). Toronto: University of Toronto Press.

Friedmann, John, \& Sorensen, André (2019). City unbound: Emerging mega-conurbations in Asia. International Planning Studies, 24(1), 1-12.

Güney, Murat, Keil, Roger, \& Üçoğlu, Murat (Eds). (2019). Massive suburbanization:

(Re)building the global periphery. Toronto: University of Toronto Press.

Gururani, Shubhra, \& Dasgupta, Rajarshi (2018) Frontier urbanism: urbanisation beyond Cities in South Asia: Frontier urbanism. Economic and Political Weekly, 53(12), 4145.

Hamel, Pierre, \& Keil, Roger (Eds.). (2015). Suburban governance: A global view. Toronto: University of Toronto Press.

Harris, Richard, \& Lehrer, Ute (Eds.). (2018). Suburban land question: A global survey. Toronto: University of Toronto Press.

Jefferson, Brian Jordan (2018). Dark side of the planet: Hidden dimensions of urban agglomeration. Urban Geography 39(10), 1581-1588.

Keil, Roger (Ed.). (2013). Suburban constellations: Governance, land and infrastructure in the 21st century. Berlin: Jovis Verlag.

Keil, Roger (2018a). Extended urbanization, "disjunct fragments” and global suburbanisms. Environment and Planning D: Society and Space 36(3): 494-511.

Keil, Roger (2018b). Suburban planet: Making the world urban from the outside in. Cambridge: Polity Press.

Keil, Roger (2018c). The empty shell of the planetary: Re-rooting the urban in the experience of the urbanites. Urban Geography, 39(10), 1589-1602.

Khan, Danish, \& Karak, Anirban (2018). Urban development by dispossession: Planetary urbanization and primitive accumulation. Studies in Political Economy, 99(3), 307330. 
Merrifield, Andy (2018). Planetary urbanisation: une affaire de perception. Urban Geography, 39(10), 1603-1607.

Peck, Jamie (2015). Cities beyond compare? Regional Studies, 49(1), 160-182.

Phelps, Nick, \& Wu, Fulong (Eds.). (2011). International perspectives on suburbanization: A post-suburban world? Basingstoke: Palgrave Macmillan.

Robinson, Jennifer (2016). Thinking cities through elsewhere: Comparative tactics for a more global urban studies. Progress in Human Geography, 40(1), 3-29.

Roy, Ananya (2009). The 21st-century metropolis: New geographies of theory. Regional Studies, 43(6), 819-830.

Shen, Jie, \& Wu, Fulong (2017). The suburb as a space of capital accumulation: The development of new towns in Shanghai, China. Antipode, 49(3),, 761-780.

Shen, Jie, \& Xiao, Yang (2019). Emerging divided cities in China: Socioeconomic segregation in Shanghai, 2000 - 2010. Urban Studies (in press).

Sheppard, Eric, Leitner, Helga, \& Maringanti, Anant (2013). Provincializing global urbanism: A manifesto. Urban Geography, 34(7), 893-900.

Simone, AbdouMaliq (2019). Maximum exposure: Making sense in the background of extensive urbanization. Environment and Planning D: Society and Space. 37(6), 990-1006.

Wilson, David, \& Jonas, Andrew (2018). Planetary urbanization: New perspectives on the debate. Urban Geography, 39(10),1576-1580.

Wu, Fulong (2016). Emerging Chinese cities: implications for global urban studies. Professional Geographer 68(2): 338-348.

Wu, Fulong (2018). Planning centrality, market instruments: Governing Chinese urban transformation under state entrepreneurialism. Urban Studies, 55(7), 1383-1399.

Wu, Fulong, \& Shen, Jie (2015). Suburban development and governance in China. In Pierre Hamel \& Roger Keil (Eds.). Suburban governance: A global view (pp. 303324). Toronto: University of Toronto Press. 